\title{
Detection of K1 antigen of Escherichia coli rods isolated from pregnant women and neonates
}

\author{
Agnieszka Kaczmarek • Anna Budzyńska • \\ Eugenia Gospodarek
}

Received: 24 September 2013 / Accepted: 27 March 2014 / Published online: 16 April 2014

(C) The Author(s) 2014. This article is published with open access at Springerlink.com

\begin{abstract}
The K1 antigen is an important virulence determinant of Escherichia coli strains and has been shown to be associated particularly with neonatal meningitis, bacteraemia and septicaemia. Thus, its detection seems to be useful, especially in the case of $E$. coli strains isolated from pregnant women and newborns. In this study, the sensitivity and specificity of the latex agglutination test (Pastorex Meningitis) for identification of $E$. coli serogroup $\mathrm{K} 1$ were assessed, using $\mathrm{PCR}$ as the gold standard. Our results showed that consistency of results between latex agglutination test and PCR amounted to $98.5 \%$. Therefore, Pastorex Meningitis is a good alternative to PCR and could be used for rapid K1 antigen detection, especially in local non-specialized laboratories with limited resources where PCR assay is not applied.
\end{abstract}

\section{Introduction}

Escherichia coli produce more than 80 different capsular polysaccharide $\mathrm{K}$ antigens. One of the most extensively studied bacterial capsules is the $\mathrm{K} 1$ serotype of $E$. coli (Whitfield and Roberts 1999). The $\mathrm{K} 1$ polysaccharide is an $\alpha$-2,8-linked linear homopolymer of $N$-acetylneuraminic (sialic acid; NeuNAc) and is identical to the polysaccharide antigens of group B Neisseria meningitidis, Pasteurella haemolytica A2 and Moraxella nonliquefaciens (Devi et al. 1991; Steenbergen et al. 2006; Vann et al. 2004). Polysialic acid is also a surface component of many fetal and adult mammalian tissues and of the neural cell adhesion molecule (N-CAM) (Bliss et al. 1996). Impossibility to present polysaccharide antigens on

A. Kaczmarek $(\bowtie) \cdot$ A. Budzyńska $\cdot$ E. Gospodarek Department of Microbiology, Ludwik Rydygier Collegium Medicum in Bydgoszcz, Nicolaus Copernicus University in Torun, 9 M. Skłodowskiej-Curie Street, 85-094 Bydgoszcz, Poland e-mail: aga_kaczmarek@poczta.onet.pl antigen-presenting cells (APC) and structural similarities between the $\mathrm{K} 1$ capsule and host tissue components may account for the poor immunogenicity of the $\mathrm{K} 1$ polysaccharide in humans and animals (Cisowska 2003; Vann et al. 2004). Molecular mimicry of the polysialic acid capsule to polysialosylglycopeptides on human fetal neuronal tissue plays an essential role in the pathogenesis of diseases caused by $E$. coli carrying the $\mathrm{K} 1$ capsule, particularly in infants and young children (Steenbergen et al. 2006; Vann et al. 2004). Furthermore, the K1 capsule provides the bacterium with an antiphagocytic barrier that inhibits the alternative pathway of complement (Moxon and Kroll 1990). Then, the K1 antigen has, in addition to its well-recognized serum resistance and antiphagocytic properties, a role in the traversal of $E$. coli across the blood-brain barrier as a live bacterium (Hoffman et al. 1999; Willis and Whitfield 2013). The K1 antigen is an important virulence determinant of $E$. coli strains and has been shown to be associated with a variety of extraintestinal diseases (Steenbergen et al. 2006). Capsule expression in E. coli has a role in virulence during urinary tract infection (UTI) and contributes to $E$. coli UTI pathogenesis by promoting biofilmlike bacterial communities in the host (Ulett et al. 2013). Moreover E. coli $\mathrm{K} 1$ is the most common cause of gramnegative neonatal meningitis, septicaemia, and bacteraemia (Bingen et al. 1996; Korczak et al. 2005; Korhonen et al. 1985; Watt et al. 2003). Despite antimicrobial therapy, these devastating diseases caused by $E$. coli $\mathrm{K} 1$ remain a major cause of high neonatal mortality and morbidity. Moreover, long-term neurological sequelae, including seizure disorders, hydrocephalus, physical disability, developmental delay and hearing loss, are common among more than half of the survivors (Korczak et al. 2005). It is therefore important to identify the K1-encapsulated $E$. coli rapidly and reliably.

Only a few studies (Cross et al. 1984; Devine et al. 1990; Gross et al. 1977) have examined the use of different methods for the detection of the K1 capsular polysaccharide among 
clinical isolates of $E$. coli, and in the available articles, there is a lack of research results of the K1 antigen detection using Pastorex Meningitis. Therefore, for the purpose of obtaining more information about the reliable detection of the $\mathrm{K} 1$ antigen, we analysed the effectiveness of $\mathrm{K} 1$ antigen identification using the latex agglutination test-Pastorex Meningitiscompared to PCR.

\section{Materials and methods}

Bacterial strains

A total of 134 genetically unrelated E. coli isolates were analysed in this study. Genotypic relatedness of these strains was assessed using pulsed-field gel electrophoresis (PFGE) analysis (data not shown). One hundred and seven E. coli strains were obtained from pregnant women from three different sources: faeces $(n=74)$, vagina $(n=21)$ and urine $(n=$ 12 ) samples. The study also included 27 E. coli strains isolated from newborns: 19 were isolated from the nasal cavity, 5 were isolated from the urine and 3 were isolated from the faecal samples. All strains were isolated from June to September 2008, from patients hospitalized at Dr. J. Biziel University Hospital No. 2, L. Rydygier Collegium Medicum in Bydgoszcz at Nicolaus Copernicus University in Torun, Poland. Permission to carry out the research was given by the Bioethics Committee of Collegium Medicum in Bydgoszcz at Nicolaus Copernicus University in Torun. Bacteria were cultured on MacConkey agar and identified by a biochemical method (ID 32E, bioMérieux).

\section{$\mathrm{K} 1$ antigen detection}

Two methods were used for K1 antigen determination: latex agglutination test (Pastorex Meningitis, Bio-Rad) and PCRbased detection of neuC (K1-specific gene).

Latex agglutination method

Latex agglutination test for the $\mathrm{K} 1$ antigen was performed using latex particles coated with mouse monoclonal antibodies specific for $N$. meningitidis/E. coli $\mathrm{K} 1$ according to the manufacturer's instruction. In the presence of the K1 antigen, the latex particles agglutinated. In the absence of this antigen, latex particles remained in a homogeneous suspension. Latex containing the polysaccharide antigens of $N$. meningitidis A, C, B and Y/W135; Haemophilus influenzae b; Streptococcus $\mathrm{B}$ and Streptococcus pneumoniae controlled the immunoreactivity of latex sensitized with the mouse monoclonal antibody specific for $N$. meningitidis group $\mathrm{B} / E$. coli $\mathrm{K} 1$, whereas latex sensitized with IgG immunoglobulins from a non-immunized rabbit controlled the absence of unspecific agglutination.
Isolation of the bacterial DNA and PCR amplification

DNA was extracted from bacteria using a Genomic Mini Purification kit (A\&A Biotechnology) according to the manufacturer's instructions. The DNA extract was stored at $-20{ }^{\circ} \mathrm{C}$ prior to PCR. The PCR assay was performed using primers specific for the gene encoding $\mathrm{K} 1$ antigen $(n e u C)$ (neuC1 5'-AGG TGA AAA GCC TGG TAG TGT G-3', neuC2 5'-GGT GGT ACA TCC CGG GAT GTC-3') (Moulin-Schouleur et al. 2007). The detected virulence gene was amplified in a total volume of $25 \mu \mathrm{L}$ containing $1.5 \times$ PCR buffer, $2 \mathrm{mM} \mathrm{MgCl}_{2}, 5 \mathrm{nmol}$ each dNTP (Promega), 12.5 pmol each primer (Laboratory of DNA Sequencing and Oligonucleotide Synthesis, IBB Polish Academy of Sciences, Poland), $1 \mathrm{U}$ Taq DNA polymerase (Promega) and $50 \mathrm{ng}$ of DNA. The amplification was done in the GeneAmp PCR System 2700 thermal cycler (Applied Biosystems). The PCR steps were as follows: initial denaturation at $94{ }^{\circ} \mathrm{C}$ for $3 \mathrm{~min}$, followed by 30 cycles of denaturation at $94{ }^{\circ} \mathrm{C}$ for $1 \mathrm{~min}$, annealing at $58^{\circ} \mathrm{C}$ for $1 \mathrm{~min}$ and extension at $72^{\circ} \mathrm{C}$ for $1 \mathrm{~min}$, followed by a final 10 -min extension at $72{ }^{\circ} \mathrm{C}$. The reaction conditions were adapted from the method of MoulinSchouleur et al. (2007). After amplification, the PCR products were separated by electrophoresis in a $1.5 \%$ agarose gel, stained in ethidium bromide solution and visualized with a GelDoc 2000 gel documentation system (Bio-Rad). During each run, the DNA template from the E. coli BEN2908 strain and Molecular Grade Water (Sigma) instead of DNA were included as positive and negative controls, respectively (Germon et al. 2005). The E. coli BEN2908 strain was provided by Dr. Pierre Germon (Unité Infectiologie Animale et Santé Publique, France).

\section{Results}

Latex agglutination test (Pastorex Meningitis) and PCR were used to identify the $E$. coli $\mathrm{K} 1$ strains. Confirmation of the results of the $\mathrm{K} 1$ surface antigen identification in $E$. coli strains using latex agglutination test and PCR was obtained for 132 $(98.5 \%)$ of the 134 tested strains. The latex agglutination method falsely identified two strains - one as K1 negative (sensitivity $98.5 \%$ ) and one as K1 positive (specificity $98.5 \%$ ) - in comparison with the PCR results (Table 1). Examples of the PCR amplification results for the gene analysed in this study are shown in Fig. 1.

\section{Discussion}

$E$. coli is the principal gram-negative rod responsible for meningitis and sepsis in newborn and premature infants. Most of the E. coli strains isolated from the cerebrospinal fluid or 
Table 1 Discrepancies between the Pastorex Meningitis test and PCR assay in identification of $E$. coli $\mathrm{K} 1$ strains

\begin{tabular}{lll}
\hline No. of isolates & \multicolumn{2}{l}{ Results } \\
\cline { 2 - 3 } & Pastorex Meningitis & PCR \\
\hline 66 & $\mathrm{~K} 1+$ & $\mathrm{K} 1+$ \\
66 & $\mathrm{~K} 1-$ & $\mathrm{K} 1-$ \\
1 & $\mathrm{~K} 1+$ & $\mathrm{K} 1-$ \\
1 & $\mathrm{~K} 1-$ & $\mathrm{K} 1+$ \\
\hline
\end{tabular}

$K 1+$ presence of $\mathrm{K} 1$ antigen $/$ neuC gene, $K 1-$ lack of $\mathrm{K} 1$ antigen $/$ neuC gene

the blood of patients with these infections possess the K1 capsular polysaccharide antigen as an essential virulence determinant. It was shown that $78-92 \%$ of neonatal meningitis E. coli (NMEC) strains were K1 positive (Bingen et al. 1997; Johnson et al. 2002; Korhonen et al. 1985; Obata-Yasuoka et al. 2002; Watt et al. 2003). The mean prevalence of the K1 antigen among the NMEC strains was higher than that among the neonatal septicaemia strains (59-70\%) (Bingen et al. 1996; Obata-Yasuoka et al. 2002; Watt et al. 2003).

The $E$. coli strains involved in a large number of neonatal diseases are thought to originate from the natural microflora of pregnant women. Vaginal colonization with $E$. coli seems to be an important step in neonatal infection, and it was observed in $24-31 \%$ of pregnant women. About half of all vaginal E. coli strains express the $\mathrm{K} 1$ antigen (Obata-Yasuoka et al. 2002; Watt et al. 2003). Also, E. coli strains isolated from the intestinal microflora of asymptomatic pregnant women often possess the capsular K1 antigen (Watt et al. 2003). The transmission of $E$. coli strains from the mother to the newborn frequently occurs during passage of the neonate through the vaginal canal. Thus, programmes to screen for vaginal and rectal colonization of pregnant women by E. coli, particularly those with the $\mathrm{K} 1$ antigen, may be effective for infection prevention.

The K1 antigen may be identified by immunological techniques such as seroagglutination, antiserum-agar diffusion test or immunoelectrophoresis. These methods identify the K1 capsule by the use of an antiserum to $N$. meningitidis group B/E. coli K1 polysaccharide (Bingen et al. 1997; Cisowska

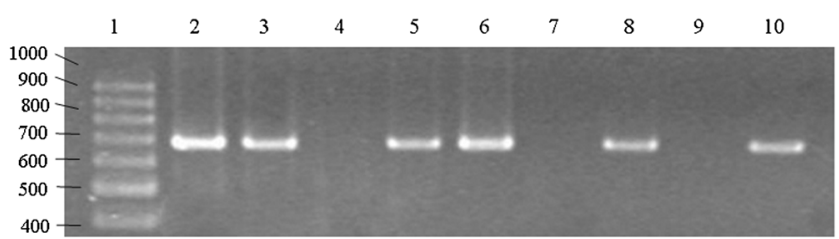

Fig. 1 Polymerase chain reaction products for the neuC (676 bp) gene. Lines: 1, DNA marker (GeneRuler ${ }^{\mathrm{TM}} 100$ bp DNA Ladder); $2-8$, tested DNA samples; 9, negative control; 10, positive control for the $n e u \mathrm{C}$ (676 bp) (E. coli strain BEN2908) gene et al. 2001; Cross et al. 1984; Obata-Yasuoka et al. 2002; Siitonen et al. 1993). Due to the fact that the K1 antigen is a poor immunogen, its detection by serological means is difficult and largely confined to specialist laboratories. An easier technique for detecting this antigen depends on the use of K1specific bacteriophages (Cisowska et al. 2001; Devine et al. 1990; Gross et al. 1977; Obata-Yasuoka et al. 2002; Siitonen et al. 1993). It is also possible to use the latex agglutination test and PCR amplification in order to identify the E. coli $\mathrm{K} 1$ strains (Kaczmarek et al. 2012; Moulin-Schouleur et al. 2007; Obata-Yasuoka et al. 2002; Siitonen et al. 1993; Watt et al. 2003). Previous studies compared the use of bacteriophage sensitivity, seroagglutination, immunodiffusion and immunoelectrophoresis techniques for the detection of the K1 capsular polysaccharide among isolates of $E$. coli (Cross et al. 1984; Devine et al. 1990; Gross et al. 1977). The results of these studies indicate that there is no one method for $\mathrm{K} 1$ detection which can be considered to be the standard.

In the present study, for the purpose of obtaining more information about a reliable method for detection of the K1 antigen, we analysed the effectiveness of the $\mathrm{K} 1$ antigen identification using latex particles coated with mouse monoclonal antibodies specific for $N$. meningitidis group $\mathrm{B} / E$. coli K1 (Pastorex Meningitis, Bio-Rad) compared to PCR. We conclude that Pastorex Meningitis is almost as accurate and reliable as PCR. Moreover, it is a rapid test that can be completed in $15 \mathrm{~min}$ as compared to the $2-3 \mathrm{~h}$ required for PCR assay. The Pastorex latex agglutination test is very easy to interpret, similar to PCR assay. In the presence of the K1 antigen, latex particles agglutinate for up to $2 \mathrm{~min}$. In the absence of this antigen, they remain in a homogeneous suspension, without visible aggregates. There was good agreement among the results obtained with this latex agglutination test and the PCR assay. The sensitivity and specificity of Pastorex Meningitis amounted to $98.5 \%$. The latex agglutination method falsely identified two strains. A false-negative result may be caused by lack of expression of the gene encoding the K1 antigen. However, the latex agglutination test is reproducible and less labour-intensive than other methods used for identification of the $E$. coli $\mathrm{K} 1$ antigen.

In conclusion, Pastorex Meningitis is a good alternative to PCR, especially in local, non-specialized laboratories with limited resources where PCR assay is not applied. Moreover, Pastorex can be performed with rapid results, which are necessary to start the appropriate treatment as soon as possible. It is important to decrease the mortality rate from invasive infection with the K1-encapsulated $E$. coli, especially among neonates.

Acknowledgments We are grateful to Dr. P. Germon (Unité Infectiologie Animale et Santé Publique, France) for the E. coli BEN2908 strain. We are also grateful to Prof. W. Szymanski (Department of Obstetrics and Gynecology, Ludwik Rydygier Collegium Medicum in 
Bydgoszcz, Nicolaus Copernicus University in Torun, Poland), Dr. P. Korbal (Department of Neonatology), M.Sc. J. Kochanowska (Department of Microbiology) and other staff at the Dr. Jan Biziel University Hospital No. 2 in Bydgoszcz, Poland, for clinical bacterial samples.

Ethical standards The authors declare that the experiments comply with the current laws of Poland.

Conflict of interest The authors declare that they have no conflict of interest. The authors do not have any financial arrangement with the BioRad company whose products figure in the submitted manuscript, and the Bio-Rad company was not involved in this study or its interpretation.

Open Access This article is distributed under the terms of the Creative Commons Attribution License which permits any use, distribution, and reproduction in any medium, provided the original author(s) and the source are credited.

\section{References}

Bingen E, Denamur E, Brahimi N, Elion J (1996) Genotyping may provide rapid identification of Escherichia coli $\mathrm{K} 1$ organisms that cause neonatal meningitis. Clin Infect Dis 22:152-156

Bingen E, Banacorsi S, Brahimi N, Elion J (1997) Virulence patterns of Escherichia coli $\mathrm{K} 1$ strains associated with neonatal meningitis. J Clin Microbiol 35:2981-2982

Bliss JM, Garon CF, Silver RP (1996) Polysialic acid export in Escherichia coli $\mathrm{K} 1$ : the role of KpsT, the ATP-binding component of an ABC transporter, in chain translocation. Glycobiology 6:445-452

Cisowska A (2003) The polysaccharide capsule of Escherichia coli K1 rods and its importance for pathogenicity of these microorganisms. Post Mikrobiol 42:3-22 (In Polish)

Cisowska A, Ruczkowska J, Doroszkiewicz W (2001) Susceptibility to antibiotics of Escherichia coli strains with K1 capsular antigen, isolated from urinary tract infections. Med Dosw Mikrobiol 53: 345-355 (In Polish)

Cross A, Orskov I, Orskov F, Sadoff J, Gemski PJ (1984) Identification of Escherichia coli $\mathrm{K} 1$ antigen. J Clin Microbiol 20:302-304

Devi SJ, Schneerson R, Egan W, Vann WF, Robbins JB, Shiloach J (1991) Identity between polysaccharide antigens of Moraxella nonliquefaciens, group B Neisseria meningitidis, and Escherichia coli $\mathrm{K} 1$ (non-O acetylated). Infect Immun 59:732-736

Devine DA, Roberts AP, Rowe B (1990) Simple technique for detecting K1 antigen of Escherichia coli. J Clin Pathol 43:76-78

Germon P, Chen YH, He L, Blanco JE, Brée A, Schouler C, Huang SH, Moulin-Schouleur M (2005) ibeA, a virulence factor of avian pathogenic Escherichia coli. Microbiology 151:1179-1186

Gross RJ, Cheasty T, Rowe B (1977) Isolation of bacteriophages specific for the K1 polysaccharide antigen of Escherichia coli. J Clin Microbiol 6:548-550

Hoffman JA, Wass C, Stins MF, Kim KS (1999) The capsule supports survival but not traversal of Escherichia coli $\mathrm{K} 1$ across the bloodbrain barrier. Infect Immun 67:3566-3570
Johnson JR, Oswald E, O’Bryan TT, Kuskowski MA, Spanjaard L (2002) Phylogenetic distribution of virulence-associated genes among Escherichia coli isolated associated with neonatal bacterial meningitis in the Netherlands. J Infect Dis 185:774-784

Kaczmarek A, Budzyńska A, Gospodarek E (2012) Prevalence of genes encoding virulence factors among Escherichia coli with $\mathrm{K} 1$ antigen and non-K1 E. coli strains. J Med Microbiol 61: $1360-1365$

Korczak B, Frey J, Schrenzel J, Pluschke G, Pfister R, Ehricht R, Kuhnert $P$ (2005) Use of diagnostic microarrays for determination of virulence gene patterns of Escherichia coli K1, a major cause of neonatal meningitis. J Clin Microbiol 43:1024-1031

Korhonen TK, Valtonen MV, Parkkinen J, Väisänen-Rhen V, Finne J, Väisänen-Rhen V, Finne J, Orskov F, Orskov I, Svenson SB, Mäkelä PH (1985) Serotypes, hemolysin production, and receptor recognition of Escherichia coli strains associated with neonatal sepsis and meningitis. Infect Immun 48:486-491

Moulin-Schouleur M, Répérant M, Laurent S, Brée A, Mignon-Grasteau S, Germon P, Rasschaert D, Schouler C (2007) Extraintestinal pathogenic Escherichia coli strains of avian and human origin: link between phylogenetic relationships and common virulence patterns. J Clin Microbiol 45:3366-3376

Moxon ER, Kroll JS (1990) The role of bacterial polysaccharide capsules as virulence factors. Curr Top Microbiol Immunol 150:65-85

Obata-Yasuoka M, Ba-Thein W, Tsukamoto T, Yoshikawa H, Hayashi H (2002) Vaginal Escherichia coli share common virulence factor profiles, serotypes and phylogeny with other extraintestinal E. coli. Microbiology 148:2745-2752

Siitonen A, Takala A, Ratiner YA, Pere A, Mäkelä PH (1993) Invasive Escherichia coli infections in children: bacterial characteristics in different age groups and clinical entities. Pediatr Infect Dis 12:606612

Steenbergen SM, Lee YC, Vann WF, Vionnet J, Wright LF, Vimr ER (2006) Separate pathways for O acetylation of polymeric and monomeric sialic acids and identification of sialyl O-acetyl esterase in Escherichia coli K1. J Bacteriol 188:6195-6206

Ulett GC, Totsika M, Schaale K, Carey AJ, Sweet MJ, Schembri MA (2013) Uropathogenic Escherichia coli virulence and innate immune responses during urinary tract infection. Curr Opin Microbiol 16:100-107

Vann WF, Daines DA, Murkin AS, Tanner ME, Chaffin DO, Rubens CE, Vionnet J, Silver RP (2004) The NeuC protein of Escherichia coli $\mathrm{K} 1$ is a UDP $\mathrm{N}$-acetylglucosamine 2-epimerase. J Bacteriol 186: 706-712

Watt S, Lanotte P, Mereghetti L, Moulin-Schouleur M, Picard B, Quentin R (2003) Escherichia coli strains from pregnant women and neonates: intraspecies genetic distribution and prevalence of virulence factors. J Clin Microbiol 41:1929-1935

Whitfield C, Roberts IS (1999) Structure, assembly and regulation of expression of capsules in Escherichia coli. Mol Microbiol 31:13071319

Willis LM, Whitfield C (2013) Structure, biosynthesis, and function of bacterial capsular polysaccharides synthesized by $\mathrm{ABC}$ transporterdependent pathways. Carbohydr Res 378:35-44 